\title{
The Effect of Entrepreneurship of SMEs on Corporate Capabilities, Dynamic Capability and Technical Performances in South Korea
}

\author{
Ho-Taek Yi ${ }^{1}$, Chang-Nam Han ${ }^{2}$, Yong-Bong $\mathrm{Cha}^{3}$
}

Received : July 27, 2018 Revised: September 17, 2018 Accepted: September 30, 2018

\begin{abstract}
There has been a recent increase in the interest towards founding companies and in line with the South Korean Government's policy on start-up support, discussions are rife about the effect of entrepreneurship on the management and performances of these companies. To enhance the competitiveness of SMEs, it is expedient to acquire and deploy consistent entrepreneurship, differentiate corporate resources, ensure the appropriate utilization of resources and the integration of such factors in response to the changing environment. This research examines relationships among entrepreneurship, three components of corporate capabilities, dynamic capability and technical performance based on resource-based view and the dynamic capability theory. The authors also investigate the moderating role of corporate life cycle. To test the hypothesis, we conducted a survey on 352 technologies -innovative SMEs located in South Korea via professional research institutes. The findings confirm the hypothesis that SMEs' entrepreneurship has a positive effect on three kinds of corporate capabilities (e.g., marketing, R\&D, operations capability), and it had a positive effect on dynamic capability, whiles dynamic capability also had an influence on technical performances. The findings also confirmed the hypothesis that corporate life cycle moderates the relationship between dynamic capability and technical performances respectively. The research implications for both practitioners and academicians are discussed.
\end{abstract}

Keywords: Entrepreneurship, Resource-Based Theory, Dynamic Capability, Corporate Life Cycle, Korea.

JEL Classification Code: M10, M13, O30.

\section{Introduction}

The degree of intense competition at the firm level has brought in its trail the need for entrepreneurial firms or SMEs to solidify their competitive positions against their rivals. This can be achieved through entrepreneurialoriented activities that allow companies to access different skills, capabilities and resources (Rosli \& Sidek, 2013). Due

1 First Author and Corresponding Author. Assistant Professor of Marketing, Department of Business Administration, Keimyung University, Daegu, South Korea [Postal Address: 1095 Dalgubuldaero, Dalseo-gu, Daegu, 42601, South Korea] Tel.82-53-5806667, Fax.82-53-580-6364 E-mail: hotaekyi@kmu.ac.kr

2 Doctoral Student, Department of Business Administration, Keimyung University, Daegu, South Korea,

E-mail: hcn0126@naver.com

3 Doctoral Student, Department of Business Administration, Keimyung University, Daegu, South Korea,

E-mail: ybong421@naver.com to the fact that venture companies are small and limited in financial and managerial personnel resources, it is critical for them to adopt and deploy entrepreneurial oriented activities in order to survive the fierce competition. For instance, a venture company that specializes in ultrasound diagnostic devices, Madison, is well-known in South Korea as the first student venture company founded in 1985 by Professor Lee Min-hwa at Korea Advanced Institute of Science and Technology. As a founder of the firm, he promoted in-house venture based on the organizational culture of encouraging the challenge and supporting the failure. He argued that Madison's performances and capabilities were acquired through a challenge and it was Madison's management by objectives. Its organizational culture and system that emphasize entrepreneurship is recognized as a benchmarking model for Korean venture management. The Korean venture business which was established in 1981 as the first registered venture firm in Korea started with the spread of the internet in the 1990s. However, currently, a full-scale boom has begun to take 
place. Presently, apart from the information technology industry, the electronic components, semiconductors, venture business are all expanding.

In a survey conducted in 2017 by the Ministry of Small and Medium-sized Venture Business in South Korea, the results indicated that the total number of venture companies is $33,289.27,906$ of these companies have less than 30 employees, accounting for $83.8 \%$ of the total. The average performance of venture companies is 10.4 years, followed by $4 \sim 10$ years with $52.9 \%, 11 \sim 20$ years with $32.6 \%, 3$ years or less with $7.4 \%$, respectively. In the survey results, $88.8 \%$ of present CEOs of venture firms were found to establish the organization, and $87.4 \%$ of the founders of venture firms were found to start the businesses alone. In this way, we can argue that corporate entrepreneurship of top management is more important than anything else in the venture business and can be easily suggested that corporate entrepreneurship is very essential for the maintenance of competitiveness and sustainable growth as a key driving force of enterprise competition

Extant research is trying to investigate the antecedents and consequences of entrepreneurship, but research that encompasses all relevant constructs in an integrated way is still limited. For instance, Hult, Hurley, and Knight (2004) assessed the role of entrepreneurship, innovativeness and performance; however, the study was contextualized in the 'Fortune 500' companies, thereby limiting the applicability of its findings in the venture companies or SMEs. Consequently, we set out to investigate the mediating role of corporate capabilities (e.g., marketing, R\&D, operation capability) and dynamic capability in the corporate entrepreneurship-performance relationship in the South Korean SME sector using the resource-based and dynamic capabilities theories as the theoretical lenses. Existing research has presented much evidence for the direct relationships between corporate entrepreneurship and corporate performances such as organizational growth (Morris \& Sexton, 1996; Wiklund, 1999) and profitability (Zahra \& Covin, 1995; Wiklund, 1999).

However, these extant studies have overlooked the interaction between corporate internal and external resources and capabilities and have focused on the direct effect between entrepreneurship and performance. Specifically, we argue that there is a positive relationship between corporate entrepreneurship and marketing, R\&D, and operations capability. It has been suggested in the literature that these capacities affect firms' dynamic capability and eventually has a positive effect on the firm's technical performance. However, we go a step ahead to investigate the moderating effect of corporate life cycle on the dynamic capability and technical performance relationship among SMEs or venture companies.

\section{Theoretical Background}

\subsection{Entrepreneurship}

Even though extant research on SME entrepreneurship has dwelt mainly on the psychological characteristics of entrepreneurs, it has been recognized that psychological characteristics are limited in explaining the complex phenomena of entrepreneurship. Consequently, the next flow of entrepreneurship research emphasizes the importance of entrepreneurial behavior. In line with the foregoing, Carland, Carland, and Stewart (1996) argue that the behavior of an entrepreneur can be a better way of understanding an entrepreneur and can be a clearer way to understand entrepreneurship as well. Subsequently, an integrated study has been attempted that assessed the characteristics and behavior of the entrepreneur (Becherer \& Maurer, 1999). As a result, scholars have recently recognized the essence of interaction among several variables related to entrepreneurship in venture firms (Wang, 2008; Wiklund \& Shephered, 2005).

Since Schumpeter's (1934) seminal definition of entrepreneurship, it has been studied in a wide variety of fields such as sociology, economics, business administration and psychology. However, it still begs for understanding why a generally acceptable definition of entrepreneurship has yet to be made. Schumpeter (1934) defined an Entrepreneur as an innovator in new ways of doing new changes in the marketplace in the process of creative destruction. Similarly, Morris, and Lewis (1995) define entrepreneurship as an innovative, enterprising and adventurous way of thinking and action to create a new value. Previous researches on entrepreneurship have described entrepreneurship as a multi-dimensional concept of innovativeness, proactiveness and risk-taking (Covin \& Lumpkin, 2011; Lassen, Gertsen, \& Riis, 2006; Covin \& Miller, 2014; Morris \& Kuratko, 2002). Schumpeter (1934) proposed Innovativeness to show that entrepreneurs play the most important role in economic activities. In line with this, Lumpkin and Dess (2001) define innovation as a tendency to pursue creative ideas and activities to create new value. The pursuit of innovation by entrepreneurs lead to product improvement or more efficient production processes that lead to more efficient management. Second, proactiveness refers to both the progressive tendency to strive for competitiveness and future-oriented and goaloriented behavioural tendencies toward market opportunities (Lyons, 2000). In addition, it can be defined as a direct and challenging attitude toward creating performances in the competition (Lumpkin \& Dess, 2001). Finally, risk-taking refers to the entrepreneur's adventurous and challenging decision-making tendency to capture 
business opportunity, which is the ability to capture new business opportunity and daringly challenging without confidence in business success (Dess, Ireland, Zahra, Floyd, Janney, \& Lane, 2003) or as preference for high-risk seeking of opportunities (Murphy, Kickul, Barbosa, \& Titus, 2007).

\subsection{Resource-based View}

According to Barney (1991), the resource-based view starts with a critique of the industrial organization theory that emphasizes the impact of environmental factors on the performance of industry to which the company belongs and explicitly looks for the internal sources of resources and capabilities and aims to explain why firms in the same industry might differ in performance. In the industrial organization theory, based on the SCP model, the structure of the industry to which the company belongs affects the corporate conduct, which causes a difference in performances between firms (Porter, 1991); and the resource-based viewpoint argues that if the business environment is the same, the difference in performances between companies belonging to the same environment is due to the acquisition of idiosyncratic resources that are difficult to imitate and replace (e.g., Amit \& Schoemaker, 1993; Mahoney \& Pandian, 1992).

Consistent with the foregoing, Barney (1997, 2002) maintain that for a company's business resources to be worthy of being a sustainable competitive advantage, it must acquire and control valuable, rare, inimitable and nonsubstitutable (VRIN) resources and capabilities, plus have the organization in place that can absorb and apply them. Barney (1991) considered resources as concepts that include all kinds of resources and capabilities, organizational process, company characteristics, information knowledge, etc., which can be operated and controlled to achieve corporate goals. In the resource-based theory, resources are either tangible or intangible assets that can help to increase the efficiency of production or increase the marketing effect to the target customers in business activities (Barney, Ketchen, \& Wright, 2011). The tangible resources include financial resources, plant facilities, buildings and equipment, and intangible resources include human resources, management knowledge and brands.

The resource-based view is one of the most influential and quoted theories in the history of management theory. It can explain internal factors of sustainable competitive advantage of a company. The central proposition of this theory is that companies must acquire and manage resources and capabilities in order to achieve a sustainable competitive advantage. This proposition is based on several related analyses: core competence (Hamel \& Prahalad,
1994), dynamic capabilities (Teece, Pisano, \& Shuen, 1997) and knowledge-based view (Grant, 1996).

\subsection{Dynamic Capability Theory}

Eisnehardt and Martin (2000) suggest that it is not possible to explain how and why companies have competitive advantages in rapid and unpredictable situations of change in a resource-based view. It is classified as conceptually vague and tautological as unrelated to the mechanism the resource actually contributes to the competitive advantage (e.g., Priem \& Butler, 2001). It has also been criticized that there is a lack of empirical evidences (e.g., Williamson, 1999), and in the dynamic market there is no sustained competitive advantage (e.g., D’Aveni, 1994).

Dynamic capability theory has been used as the most important term in strategic research since the late 1990's. In an earlier work on dynamic capability, Teece, Pisano, and Shuen (1997) suggested that the term 'dynamic capability' is "organizational and strategic routines for companies to achieve new resource configuration as the market emerges, collides, divides, evolves, and dies.' This definition is similar to the definitions given by other authors. For example, 'combinative capabilities' (Kogut \& Zander, 1992), 'architectural competence' (Henderson \& Cockburn, 1994), and 'capabilities' (Amit \& Schoemaker, 1993) to describe organizational processes that firms acquire by synthesizing knowledge resources and generate new applications from those resources. In a relatively recently study, Teece (2007) defined the dynamic capability as the ability to adapt to internal and external environments that change to maintain a sustainable competitive advantage, to integrate and reorganize resources and competency of organizational structures within the firm, and to learn new competencies. Therefore, we argue that dynamic capability is the ability to integrate and coordinate the resources by the firm, which is a major source of competitive advantage in the competitive market.

The components of dynamic capabilities are defined differently by scholars. For instance, Pavlou and El Sawy (2011) identify a set of capabilities such as sensing the environment, learning, coordinating, and integrating. Wu (2010) proposes resource integration capability, learning capability, and resource reconfiguration capability as the components of dynamic capabilities. In summary, when we summarize the detailed components of the dynamic capability, we can posit the following: sensing the environment capability (the ability to quickly identify market opportunities and risks under changing environment), learning capability (learning and absorbing new external knowledge in the internal organization), coordinating and 
integrating capability (the ability to integrate newly acquired capabilities with existing capabilities), and reconfiguration capability (the capability to appropriately converge and integrate the acquired capability to suit the firm's internal characteristics to create new knowledge).

We argue that there are several meanings to the identification of specific processes as dynamic capabilities. For example, considering the large-scale and substantial system of empirical research that is often ignored within the paradigm, it opens resource-based view. As we mentioned above, a major criticism against resource-based view is the lack of empirical grounding. By defining dynamic capabilities from the perspective of functional relationship with resource manipulation, value is defined independent of business performances which is a recipe for empirical falsification.

\section{Research Model and Hypotheses}

\subsection{Research Model}

We proposed a research model as shown in <Figure 1> and tested the hypotheses. In the model, we hypothesized that the entrepreneurship of venture firms has a positive effect on internal capabilities (Marketing capability-H1, R\&D capability- $\mathrm{H} 2$, and operations capability-H3). These three corporate capabilities affect the dynamic capability $(\mathrm{H} 4-\mathrm{H} 6)$ and ultimately the dynamic capabilities have a positive effect on the technical performance of SMEs $(\mathrm{H} 7)$. Furthermore, we posit that the corporate life cycle plays a moderating role in the relationship between the dynamic capability of small companies and their technical performance (H8).

\subsection{Hypotheses}

\subsubsection{Relationship between Entrepreneurship and Marketing Capabilities}

The extant literature defines entrepreneurship as a multidimensional concept that reflects the psychological characteristics of an entrepreneur and the behavior of an entrepreneur. As we have intimated earlier, the components of the entrepreneurship construct involve three dimensions such as innovativeness, proactiveness, and risk-taking, act together to form a unidimensional 'gestalt' and be gathered together when measuring entrepreneurship (Covin \& Lumpkin, 2011; Covin \& Miller, 2014; Lassen, Gertsen, \& Riis, 2006).

According to McDougall, Oviatt and Shrader (2003), entrepreneurship is closely related to the internal capabilities of a firm. Consistent with this, Luo and Shi (2002) maintain that entrepreneurship is a kind of business culture that enthusiastically enters new market and nurtures firms that introduce new products. They argued that a firm will behave more creatively, more intimately, and more bravely to perform new business, if employees have entrepreneurship in their work. Moreover, Weerawardena and O'cass (2004) contended that entrepreneurship plays an important role for its market orientation capability and development of new products (e.g. Kinght, 2000). Following from the foregoing, we set the following hypothesis:

Hypothesis 1: Entrepreneurship of SMEs will have a positive and significant effect on marketing capability.

\subsubsection{Relationship between entrepreneurship and $R \& D$ capability}

Drucker (1985) suggested that social services, economic activities, public institutes and private firms all need entrepreneurship to gain innovation and development. Entrepreneurship helps to realize innovative idea, including new products, new services, new production processes, new technologies, new materials and new business models (Lee \& Hsieh, 2010). Again in the literature, Krasnikov and Jayachandran (2008) argued that R\&D is a firm's ability to develop new products or services with existing technologies. Based on this, we set the following hypothesis:

Hypothesis 2: Entrepreneurship of SMEs will have a positive effect on R\&D capabilities.

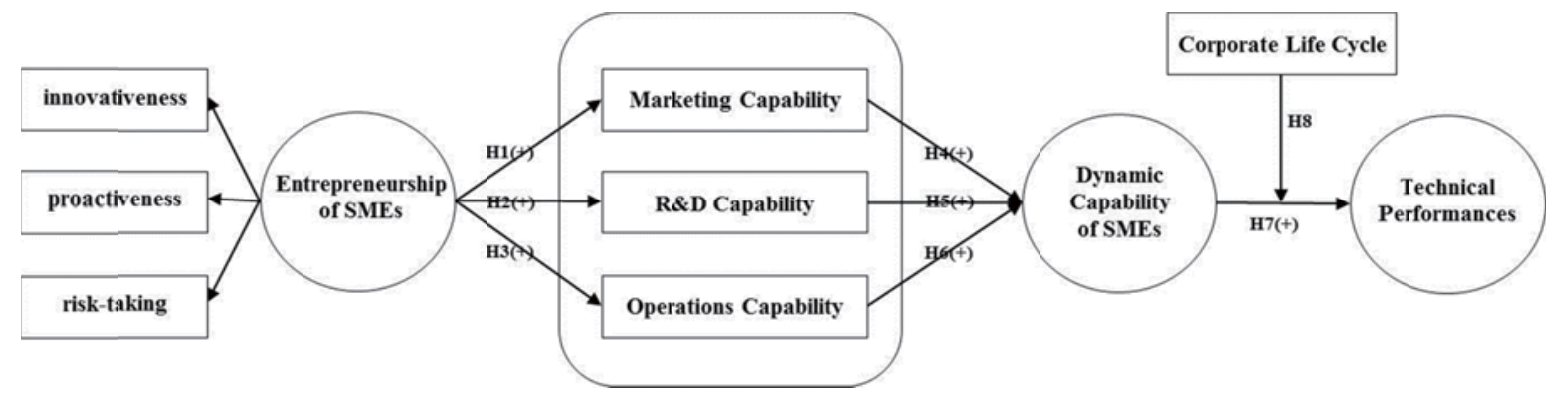

Figure 1: Research Model 


\subsubsection{Relationship between Entrepreneurship and Operations Capability}

According to Lumpin and Dess (1996), entrepreneurship can be defined as a learning and selection mechanism that creates exploratory, risk-seeking behaviors in the operation innovation process. Operation capability refers to the ability of a company to control resources to minimize the wastage of resources through productivity enhancement of the various sources possessed by the company. This is related to efficient manufacturing and logistics systems (Krasnikov \& Jayachandran, 2008). Operation innovation initiatives facilitated by entrepreneurship orientation include combinations of new resources that may currently require capabilities not currently available within the organization, which is associated with greater risk-taking and experimentation (Levinthal \& March, 1993). In some respects, it is similar to the technological orientation to improve corporate capability and acquire new technical knowledge to build new operation solutions (Gatignon \& Xuereb, 1997). Based on the above discussions, we suggest the following hypothesis:

Hypothesis 3: Entrepreneurship of SMEs will have a positive effect on operations capability.

\subsubsection{Relationship between Corporate Capabilities and Dynamic Capability}

The literature about dynamic capability theory shows that companies benefit from having dynamic capabilities when developing new business and corporate strategies (Bowman \& Ambrosini, 2003); learning new skills (Zollo \& Winter, 2002); overcoming inertia (King \& Tucci, 2002); utilizing other resources (Bowman \& Ambrosini, 2003); introducing innovative program to stimulate strategic change (Repenning \& Sterman, 2002); and successfully commercializing new technologies generated by their R\&D department (Marsh \& Stock, 2003).

Previous study suggests that dynamic capabilities are important for the creation and evolution of new ventures (Newbert, 2005). These companies need to improve their skills and competencies to survive, achieve legitimacy, and reap the benefit of their innovation (Sapienza, Autio, Geroge, \& Zahra, 2006). Both the resource-based view and the dynamic capability theory are all based on the company's resources. From a resource-based view perspective, it is argued that the difference in performances between firms in an industry differ in terms of resources and capabilities held by the firm. Whereas the dynamic capability perspective pointed out if a firm has valuable, rare, inimitable, and nonsubstitutable resources. Without coordination, integration and redeployment processes, the company cannot maintain competitive advantage in a complex and highly volatile external environments. Thus, we can infer that these firmspecific internal capabilities such as marketing, R\&D, and operation capability affect the dynamic capability. Consequently, we set the following hypotheses:

Hypothesis 4: Marketing capability of SMEs will have a positive effect on dynamic capability.

Hypothesis 5: R\&D capability of SMEs will have a positive effect on dynamic capability.

Hypothesis 6: Operation capability of SMEs will have a positive effect on dynamic capability.

\subsubsection{Relationship between Dynamic Capability and Technical Performances}

It has been suggested in the extant literature that dynamic capability enhances performances by increasing companies' agility and strategic flexibility. For instance, Anand (2001) argues that a dynamic alliance capability allows new forms of knowledge to select forms with good and reliable partners, effectively build relationships and improve performance. Consistent with the above, Teece, Pisano, and Shuen (1997) note those dynamic capabilities update companies' competencies to improve performances, especially in dynamic markets. Likewise, Rindova, and Taylor (2002) argues that dynamic management capabilities are essential to improve the management skills of companies to find and exploit opportunities in evolving environments. Daniel and Wilson (2003) also gives credibility to the above by suggesting that dynamic capabilities promote success of organizational transformational efforts. These views reflect the general tone of the literature on the value of dynamic capabilities to improve corporate performance.

The existing literature holds three broad views on the impact of dynamic capability on corporate performance. One is the view that dynamic capability has a direct impact on the company's superior performances (Makadok, 2001; Teece, Pisano, \& Shuen, 1997; Zollo \& Winter, 2002), and another is dynamic capability has an indirect effect on corporate performances (Kogut \& Zander, 1992; Zott, 2003). The other is dynamic capability, which itself does not lead to superior corporate performances (Eisenhardt \& Martin, 2000; Helfat, Finkelstein, Mitchell, Peteraf, Singh, Teece, \& Winter, 2009); it depends on how agile the entrepreneur or manager is using dynamic capability. These positions suggest that dynamic capability directly or indirectly influences the performance of the firm. In particular, in this study, we measured corporate performance as technical performances rather that sales performance which includes the efforts to acquire intellectual property rights for technological innovation and to develop new products and improve quality based on such efforts. In general, technical performances are less influenced by the external 
environment and can be achieved by employing the dynamic capability of the entrepreneur or managers. Based on the foregoing, we set the following hypothesis:

Hypothesis 7: Dynamic capability of SMEs will have a positive effect on technical performances.

\subsubsection{Moderating Effect of Corporate Life Cycle on the Relationship between Dynamic Capability and Technical Performances of Venture Firms}

Teece, Pisano, and Shuen (1997) assume dynamic capability is the ability of an enterprise to respond quickly to changing circumstances. The usefulness of dynamic capabilities is undoubtedly greater in dynamic environments. Along with this, Zahra, Sapineza, and Davidsson (2006) explain that dynamic capability are demonstrated from various situations, timing, and effect are different. They also argue that the creation of dynamic capability can start from very early stages of the organization's lifetime. Consistently with this, Cyert and March (1963) recognizes that when the environment changes, organizations are more likely to change where to find their goals, priorities, new knowledge and opportunities. In order for companies to compete in a highly violent and intense environment like a high-tech industry, we will recognize the need to reconfigure functions repeatedly. However, the necessity of reconfiguration and routine updating may result from changes in the organizational conditions rather than the external environment (Zahra, Sapienza, \& Davidsson, 2006). It has been overlooked in the literature to judge whether a capability is 'dynamic' according to the change rate of the external environment of the company.

Corporate life cycle comprises five common stages: birth, growth, maturity, revival, and decline. Scholars predict each stage would manifest integral complementarities among variables of environment, strategy, structure and decision making methods (Miller \& Friesen, 1986). The birth phase, which is called "Entrepreneurial Stage", is characterized by much struggling and a period that needs substantial risk taking (Miller \& Friesen, 1986). The growth phase, which is called "rapid growth stage", is the stage of expected rapid growth of the firm. In this theory, these two phases are more volatile than the other three stages. Therefore, we argue that if dynamic capability develops in response to a variety of environmental conditions, it will have different effects on technology performances depending on which corporate life stage a company finds itself. Consequently, we can hypothesize that:

Hypothesis 8: The corporate life cycle will moderate the relationship between dynamic capability and technical performances: Dynamic capabilities will be more strongly associated with technology performances when corporate life cycle is in initial phase (e.g., birth or growth) than when it is in later phase (e.g., maturity, revival, and decline).

\section{Empirical Analysis and Results}

\subsection{Data collection}

We conducted a survey through a specialized research institute. A total of 352 SMEs in South Korea participated in this study. Industry characteristics of the sample respondents are shown in Table 1. It is observed that industry category and majority of the industry is in the order of machines and equipment $(21.6 \%)$ car and trailer $(178.8 \%)$ and clothes and fur (11.1\%). The average business running period was 18 years, with the average number of employees and average sales in 2017 being 60 and 47.09 billion dollars respectively.

Table 1: Industry Characteristics of the Sample

\begin{tabular}{|c|c|c|c|c|c|}
\hline Industry Category & $\mathbf{N}$ & $\%$ & Industry Category & $\mathbf{N}$ & $\%$ \\
\hline $\begin{array}{c}\text { Electronic } \\
\text { Components, } \\
\text { Computers, Images \& } \\
\text { Sound Equipment }\end{array}$ & 6 & 1.7 & $\begin{array}{c}\text { Medical, Precision } \\
\text { and } \\
\text { Optical Instruments }\end{array}$ & 12 & 3.4 \\
\hline Clothes and Fur & 39 & 11.1 & $\begin{array}{c}\text { Electrical } \\
\text { Equipment }\end{array}$ & 16 & 4.5 \\
\hline $\begin{array}{c}\text { Leather, Bag, and } \\
\text { Shoes }\end{array}$ & 11 & 3.1 & $\begin{array}{c}\text { Other Machines } \\
\text { and Equipment }\end{array}$ & 76 & 21.6 \\
\hline Chemicals & 8 & 2.3 & Cars and Trailers & 66 & 18.8 \\
\hline $\begin{array}{c}\text { Rubber and Plastic } \\
\text { Products }\end{array}$ & 20 & 5.7 & $\begin{array}{c}\text { Other Transport } \\
\text { Equipment }\end{array}$ & 6 & 1.7 \\
\hline Primary Metals & 10 & 2.8 & Furniture & 11 & 3.1 \\
\hline Metal Processing & 36 & 10.2 & Other Products & 27 & 7.7 \\
\hline Textile Product & 8 & 2.3 & Total & 352 & 100.0 \\
\hline
\end{tabular}

\subsection{Operational Definition and Measurement of Variables}

In this study, multiple items were used for each of the theoretical constructs. All construct measures were retrieved from existing literature sources using 5 point Likert-type scales. Entrepreneurship is the second-order reflective construct with three dimensions. This construct is a collective measure consisting of three dimensions: innovativeness, proactiveness, and risk-taking (Covin \& Slevin, 1989; Wiklund, 1999). Innovativeness was measured in the items of Hurley and Hult (1998). Furthermore, the 
authors used the items of Morgan and Strong (2003) to measure the way of risk-taking and proactiveness. In line with Krasnikov and Jayachandran (2008), we classified corporate capabilities as 3 different capabilities such as marketing capability, R\&D capability, and operations capability. We defined marketing capability as the organizational competence that supports market sensing and customer linking (Krasnikov \& Jayachandran, 2008). We assessed marketing capability using multi-item measures developed by Vorhies and Morgan (2005). We used four distinct marketing capability items: marketing planning, marketing information management, price forecasting and marketing implementation. R\&D capability refers to the process that enables firms to invent new technology and convert existing technology to develop new products and services (Krasnikov \& Jayachandran, 2008). R\&D capability was measured through technological area experience, technological innovativeness, innovativeness of patents, and R\&D human resource competence (Macher \& Boerner, 2006; Menguc \& Auh, 2006). Operations capability has been measured through scales of its various dimensions, such as flexibility, cost efficiency, (Tan, Kannan, Jayaram, \& Narasimhan, 2004), and product competence (Vickery, Droge, \& Markland, 1997).

Dynamic capability refers to the ability to adapt to the changing internal and external environment to maintain a sustainable competitive advantage, to integrate and reorganize resources and capabilities within the enterprise, and to learn new competencies (Teece, 2007). Following the method of Eisenhardt and Martin (2000) and Wu (2010), four items were used to measure dynamic capabilities: resource integration, learning, resource coordination and resource reconfiguration capability. Technical performances refer to the achievements that result from technological innovation of the company (Swamidass \& Newwell, 1987). We acquired technical information, numbers of independent $R \& D$, innovative NPD, intellectual property acquisition, and quality improvement, as reported by survey respondents (Levin, 1988). Finally, the corporate life cycle was measured by birth, growth, maturity, revival, and decline (Miller \& Friesen, 1986).

The data for all the constructs were obtained from the same source of the current study, using a self-report questionnaire. Therefore, there is a possibility that a common method variance may have occurred. The authors evaluated the potential problem of single factor analysis for all items (Podsakoff \& Organ, 1986). As expected, an unrotated factor analysis extracted 6 different factors, accounted for $68.25 \%$ of the total variance, and the first accounted for $36.24 \%$. Therefore, no single factor appeared, and none of the factors account for the majority of the variance.

\subsection{Reliability and Validity Analysis}

From the analysis, Cronbach's a test was conducted to measure the internal consistency of the variables measured in multiple items. As a result, as shown in $\langle$ Table 2>, all the variables showed values above the threshold value of 0.7 or more (Nunnally \& Bernstein, 1994). In addition, Confirmatory Factor Analysis (CFA) was conducted to test the reliabilities and validities of the measures. CFA revealed an adequate model fit for the proposed measurement model. CFA model fit was $x^{2}=426.581$, d.f. $=298, \quad x^{2} / d f=1.431$, RMR $=0.021, \quad$ RMSEA $=0.035, \quad G F I=0.918, \quad N F I=0.933$, IFI=0.979, TLI=0.975, CFI=0.971.

In assessing measure reliability, Fornell and Larcker (1981) emphasize the importance of verifying construct reliability (CR) and average variance extracted (AVE). Bagozzi and Yi (1988) present two criteria for evaluating reliability. The estimated value of each measurement scale must be 0.60 or more and the AVE must be 0.50 or more. As shown in <Table 2>, CR and AVE requirements were satisfied. This is because the scale of multiple items exceeded the recommended cut-off standards 0.60 and 0.50 , respectively.

Prior to the hypothesis testing, we analyzed the relationship between the variables and conducted a correlation analysis to verify the discriminant validity. As shown in <Table 3>, correlations between variables deduced from the hypothesis were found to be consistent with the overall hypothesis, and the AVE value of the fraction was larger than the square of the correlation value in all variables (Fornell \& Larcker, 1981).

\subsection{Hypothesis Testing}

The data were analyzed using AMOS 18.0. Accordingly, a structural equation modeling approach (Bentler \& Dudgeon, 1996) was used to test the hypothesized structural model against the data collected from the sample. Regarding the observed items, one parameter estimate for each latent variable was constrained to a value of 1 to facilitate the analysis (Arbuckle \& Wothke, 1999), to facilitate analysis, and maximum likelihood estimation is modeled. The final version of the model and its standardized path coefficient estimates are shown in <Table $4>$. Each of the paths was statistically significant $(p<0.05$, two-tailed test). The results of the research model revealed the following fit indices: $x^{2}=661.781, \quad$ d.f. $=306, \quad x^{2} / d f=2.163, \quad R M R=0.070$, RMSEA $=0.058, \quad \mathrm{GFI}=0.878, \quad \mathrm{NFI}=0.896, \quad \mathrm{IFI}=0.941$, $\mathrm{TLI}=0.932, \mathrm{CFI}=0.941$. Most of the fitness indices exceeded the recommended values except for the fitness index, which is acceptable (Hair, Black, Babin, Anderson, \& Tatham, 2006). 
Table 2: Results of CFA and Cronbach's a

\begin{tabular}{|c|c|c|c|c|c|c|c|c|c|}
\hline \multicolumn{4}{|c|}{ Construct } & st. estimate & S.E. & C.R. & AVE & CR & Cronbach's a \\
\hline \multirow{3}{*}{$2^{\text {nd }}$ order } & Innovativeness & $\leftarrow$ & \multirow{3}{*}{ Entrepreneurship } & 0.928 & - & - & \multirow{3}{*}{0.816} & \multirow{3}{*}{0.929} & \multirow{3}{*}{0.920} \\
\hline & Proactiveness & $\leftarrow$ & & 0.978 & 0.099 & 12.842 & & & \\
\hline & Risk-taking & $\leftarrow$ & & 0.793 & 0.095 & 11.560 & & & \\
\hline & INV 1 & $\leftarrow$ & \multirow{3}{*}{ Innovativeness } & 0.703 & - & - & \multirow{3}{*}{0.647} & \multirow{3}{*}{0.845} & \multirow{3}{*}{0.840} \\
\hline & INV 2 & $\leftarrow$ & & 0.830 & 0.081 & 14.358 & & & \\
\hline & INV 3 & $\leftarrow$ & & 0.871 & 0.084 & 14.940 & & & \\
\hline & PA 1 & $\leftarrow$ & \multirow{3}{*}{ Proactiveness } & 0.845 & - & - & \multirow{3}{*}{0.711} & \multirow{3}{*}{0.881} & \multirow{3}{*}{0.881} \\
\hline & PA 2 & $\leftarrow$ & & 0.850 & 0.054 & 19.603 & & & \\
\hline & PA 3 & $\leftarrow$ & & 0.835 & 0.054 & 19.075 & & & \\
\hline & RT 1 & $\leftarrow$ & \multirow{3}{*}{ Risk-taking } & 0.869 & - & - & \multirow{3}{*}{0.630} & \multirow{3}{*}{0.831} & \multirow{3}{*}{0.810} \\
\hline & RT 2 & $\leftarrow$ & & 0.903 & 0.052 & 20.169 & & & \\
\hline & RT 3 & $\leftarrow$ & & 0.566 & 0.059 & 11.196 & & & \\
\hline & MTC 1 & $\leftarrow$ & \multirow{4}{*}{$\begin{array}{l}\text { Marketing } \\
\text { Capability }\end{array}$} & 0.768 & - & - & \multirow{4}{*}{0.571} & \multirow{4}{*}{0.842} & \multirow{4}{*}{0.856} \\
\hline & MTC 2 & $\leftarrow$ & & 0.722 & 0.056 & 16.511 & & & \\
\hline & MTC 3 & $\leftarrow$ & & 0.786 & 0.068 & 13.865 & & & \\
\hline & MTC 4 & $\leftarrow$ & & 0.744 & 0.067 & 13.208 & & & \\
\hline & OPC 1 & $\leftarrow$ & \multirow{3}{*}{$\begin{array}{l}\text { Operations } \\
\text { Capability }\end{array}$} & 0.726 & 0.091 & 10.425 & \multirow{3}{*}{0.599} & \multirow{3}{*}{0.817} & \multirow{3}{*}{0.827} \\
\hline & OPC 2 & $\leftarrow$ & & 0.849 & 0.071 & 15.531 & & & \\
\hline & OPC 3 & $\leftarrow$ & & 0.742 & - & - & & & \\
\hline & RNDC 1 & $\leftarrow$ & \multirow{3}{*}{$\begin{array}{c}\text { R\&D } \\
\text { Capability }\end{array}$} & 0.743 & - & - & \multirow{3}{*}{0.569} & \multirow{3}{*}{0.798} & \\
\hline & RNDC 2 & $\leftarrow$ & & 0.758 & 0.104 & 11.128 & & & 0.834 \\
\hline & RNDC 3 & $\leftarrow$ & & 0.762 & 0.104 & 11.183 & & & \\
\hline & DC 1 & $\leftarrow$ & & 0.834 & & & & & \\
\hline & DC 2 & $\leftarrow$ & Dynamic & 0.845 & 0.050 & 19.001 & 0703 & 0.904 & 0904 \\
\hline & DC 3 & $\leftarrow$ & Capability & 0.876 & 0.053 & 20.054 & 0.100 & ד & ד.00 \\
\hline & DC 4 & $\leftarrow$ & & 0.796 & 0.056 & 17.398 & & & \\
\hline & TPERF 1 & $\leftarrow$ & & 0.725 & & & & & \\
\hline & TPERF 2 & $\leftarrow$ & Technological & 0.636 & 0.054 & 16.024 & 0505 & ר & 0851 \\
\hline & TPERF 3 & $\leftarrow$ & Performances & 0.704 & 0.083 & 10.205 & 0.000 & 0.002 & 1 \\
\hline & TPERF 4 & $\leftarrow$ & & 0.771 & 0.084 & 10.873 & & & \\
\hline
\end{tabular}

Model fit: $\mathrm{X}^{2}=426.581, \mathrm{df}=298, \mathrm{X}^{2} / \mathrm{df}=1.431, \mathrm{RMR}=0.021, \mathrm{RMSEA}=0.035, \mathrm{GFI}=0.918, \mathrm{NFI}=0.933, \mathrm{IFI}=0.979, \mathrm{TLI}=0.975, \mathrm{CFI}=0.979$.

Table 3: Correlation Matrix and Descriptive Statistics

\begin{tabular}{|c|c|c|c|c|c|c|c|c|c|c|}
\hline construct & Mean & SD & (1) & (2) & (3) & (4) & (5) & (6) & (7) & (8) \\
\hline Innovativeness (1) & 3.643 & .662 & 1 & $.789^{* *}$ & $.620^{* *}$ & $.287^{* *}$ & $.393^{* *}$ & $.322^{* *}$ & $.385^{* *}$ & $.462^{* *}$ \\
\hline Proactiveness (2) & 3.662 & .709 & & 1 & $.679^{* *}$ & $.289^{\star *}$ & $.401^{* *}$ & $.360^{* *}$ & $.378^{* \star}$ & $.485^{\star *}$ \\
\hline Risk-taking (3) & 3.366 & .679 & & & 1 & $.171^{\star *}$ & $.308^{* *}$ & $.275^{* *}$ & $.275^{\star \star}$ & $.398^{* \star}$ \\
\hline Marketing Capability (4) & 3.372 & .638 & & & & 1 & $.357^{* *}$ & $.480^{\star *}$ & $.637^{* *}$ & $.360^{\star *}$ \\
\hline R\&D Capability (5) & 3.550 & .744 & & & & & 1 & $.481^{* *}$ & $.420^{* *}$ & $.548^{\star \star}$ \\
\hline Dynamic Capability (7) & 3.322 & .651 & & & & & & & 1 & $.409^{* \star}$ \\
\hline Technological Capability (8) & 3.112 & .635 & & & & & & & & 1 \\
\hline
\end{tabular}


Table 4: Results of SEM for Tests of Hypotheses

\begin{tabular}{|c|c|c|c|c|c|}
\hline \multicolumn{2}{|c|}{ Path } & St. estimate & S.E. & t-value & Result \\
\hline $\mathrm{H} 1(+)$ & Entrepreneurship $\rightarrow$ Marketing Capability & 0.391 & 0.081 & 6.028 & supported \\
\hline $\mathrm{H} 2(+)$ & Entrepreneurship $\rightarrow$ Operations Capability & 0.462 & 0.077 & 6.901 & supported \\
\hline $\mathrm{H} 3(+)$ & Entrepreneurship $\rightarrow$ R\&D Capability & 0.551 & 0.09 & 7.440 & supported \\
\hline $\mathrm{H} 4(+)$ & Marketing Capability $\rightarrow$ Dynamic Capability & 0.601 & 0.056 & 10.029 & supported \\
\hline $\mathrm{H} 5(+)$ & Operations Capability $\rightarrow$ Dynamic Capability & 0.239 & 0.056 & 4.374 & supported \\
\hline $\mathrm{H} 6(+)$ & R\&D Capability $\rightarrow$ Dynamic Capability & 0.218 & 0.051 & 4.083 & supported \\
\hline $\mathrm{H} 7(+)$ & Dynamic Capability $\rightarrow$ Technological Performances & 0.529 & 0.076 & 7.050 & supported \\
\hline
\end{tabular}

Model fit: $x^{2}=661.781, \mathrm{df}=306, x^{2} / \mathrm{df}=2.163, \mathrm{RMR}=0.070, \mathrm{RMSEA}=0.058, \mathrm{GFI}=0.878, \mathrm{NFI}=0.896, \mathrm{IFI}=0.941, \mathrm{TLI}=0.932, \mathrm{CFI}=0.941$

All hypotheses from hypothesis 1 to hypothesis 7 set in the study were supported. Hypothesis 8 is a multi-group analysis through AMOS meant to examine the moderating effect of the corporate life cycle on the relationship between dynamic capability and technological performances. Multigroup analysis is the most widely employed methods to test the differences between two groups. In order to ensure homogeneity and inter-group heterogeneity in the group, the moderating variables are divided into two groups and the difference between the groups is analyzed (Stone \& Hollenbeck, 1989). As a result of multi-group analysis, the difference of $x^{2}$ between the free and constrained models exceeded 3.84, which is the threshold value, and the direction and influence of the variables are shown in $<$ Table $5>$.

Table 5: Results of Multi-group Analysis: Moderating Effect of Corporate Life Cycle

\begin{tabular}{|c|c|c|c|c|}
\hline H & \multicolumn{2}{|c|}{ Path } & \multicolumn{2}{|c|}{ Path Co-efficient } \\
\hline \multirow{3}{*}{ H8 } & $\begin{array}{l}\text { Constraint } \\
\text { model }\end{array}$ & $X_{(613)^{2}}{ }^{2}=1080.123$ & $\begin{array}{l}\text { Corporate } \\
\text { Life Cycle }\end{array}$ & $\begin{array}{c}\text { St. } \\
\text { estimate }\end{array}$ \\
\hline & $\begin{array}{l}\text { Free model } \\
\text { Dynamic }\end{array}$ & \multirow{2}{*}{$\begin{array}{l}X_{(612)}{ }^{2}=1076.213 \\
\Delta X_{(1)}{ }^{2}=3.910 \mathrm{sig}\end{array}$} & $\begin{array}{c}\text { Initial Phase } \\
\text { (birth and } \\
\text { growth) }\end{array}$ & $0.567^{\star \star}$ \\
\hline & $\begin{array}{c}\text { Capability } \rightarrow \\
\text { Technological } \\
\text { Performances }\end{array}$ & & $\begin{array}{l}\text { Later Phase } \\
\text { (maturity, } \\
\text { revival, and } \\
\text { decline) }\end{array}$ & $0.472^{* *}$ \\
\hline
\end{tabular}

\subsection{Further Analysis}

In this study, we identified entrepreneurship as $2^{\text {nd }}$ order construct of innovativeness, proactiveness, and risk-taking. However, we considered effects of individual factors consisting of entrepreneurship on marketing, R\&D, and operations capacities of SMEs may be different. As a result of direct effect analysis of each component of entrepreneurship, innovativeness had a positive effect on marketing capability $(\beta=0.272, \quad p<0.01)$, production capability $(\beta=0.225, p<0.01)$ and $R \& D$ capability $(\beta=0.299$, $p<0.01$ ), and proactiveness had a positive effect on operations capability $(\beta=0.368, p<0.01)$ and $R \& D$ capability $(\beta=0.379, \quad p<0.01)$. However, risk-taking was negatively correlated with marketing competence $(\beta=-0.159, p<0.01)$, and operations capability $(\beta=-0.117, p<0.05)$.

\section{Conclusions and Implications}

\subsection{Summary and Implications of the Study}

This study investigated the relationship between entrepreneurship as a precursor of corporate capabilities and the effects of corporate capabilities and dynamic capabilities on technical performances in small and mediumsized enterprises based on resource-based view and the dynamic capability theory. In addition, this study explored several gaps of literature and contributes to a theoretical extension of entrepreneurship and corporate capabilities research field as follows. First, despite its direct/indirect effect on entrepreneurial firms, the number of studies took into account its direct effect on performances. In this regard, our study attempts to account for the effect of entrepreneurship as an antecedent, forming a solid basis for corporate capabilities. Our findings empirically confirm that entrepreneurship of SMEs plays an important role in creating corporate capabilities and further outcomes. Second, previous literature considered dynamic capability as one of corporate capabilities and overlooked the differences between corporate capabilities possessed internally by a firm and dynamic capability which created by interaction between internal and external resources. As dividing corporate capabilities into two different types, we expect to contribute various future studies dealing with relationship between corporate capabilities and dynamic capability. Third, previously, a number of studies have divided financial performance and non-financial performance into corporate performance, and there are not many studies focusing on technical performance relatively. 
However, since SMEs or venture firms have limited resources or capabilities to be able to utilize and there are uncontrollable external factors affected financial performances, entrepreneurship and corporate capabilities are likely to affect technical performances such as numbers of independent R\&D, intellectual property acquisition, and quality improvement rather than financial performances. Therefore, our study is expected to contribute to research on the technical performances in SMEs in the future.

Based on the analysis and results of the current study, the following conclusions and managerial implications can be made from the perspective of SMEs. First, the result of our research suggest that entrepreneurship has an impact on the three (3) components of corporate capabilities, with the greatest impact being on $R \& D$ capabilities. This result illustrate why entrepreneurship is especially important for developing R\&D capability of entrepreneurs or venture firms. Although there is no statistically significant difference in the effect of entrepreneurship on marketing capability and operations capability, this is attributable to the fact that the survey was conducted on manufacturers related to technology. Secondly, marketing capability is the most influential factor in dynamic capability among corporate internal capabilities. When we look at dynamic capability as a concept of aggressive utilization beyond discriminatory resources, marketing activities are the most active activity in utilizing the resources that are possessed. Therefore, based on the outcome, we posit that marketing capability is the core capability that a company must have in order to secure and maintain a competitive advantage. Finally, the fact that corporate life cycle has a moderating effect on the relationship between dynamic capability and technical performances suggests that reinforcement of dynamic capability in early corporate life cycle can maximize the technological performances.

\subsection{Limitations and Future Research}

Akin to every research study, this research also has some limitations and directions for future research. First, the sample was composed mainly of manufacturing SMEs. Regardless of whether the findings can be generalized to other services, there are empirical questions in the retail industry and completely different industries. Therefore, in subsequent research to determine whether the results are actually generalizable and whether there are differences between industries. Second, the authors have classified the corporate capabilities as marketing, R\&D, and operations capability, but there are likely to be other capabilities. Future empirical work could examine different capabilities from those utilized here. These could include learning capability, adaptive capability, and information acquisition capability and other more diverse capabilities. Third, we examined the moderating effect of the corporate life cycle. In the first questionnaire, corporate life cycle was divided into 5 phases. Therefore, further research is required to identify the differences in the stages of corporate life cycle through additional sample collection. Finally, because this study is cross-sectional in nature, future research needs to consider the change of the relationship of variables over time.

\section{References}

Amit, R., \& Schoemaker, P. J. H. (1993). Strategic assets and organizational rent. Strategic Management Journal, 14(1), 33-46.

Anand, J. (2001). An examination of dynamic capabilities: is evolutionary theory under determined? Retrieved September 22, 2018 from: http://www.utdt.edu/congresos/ pdf-sri/eee-363.pdf.

Arbuckle, J. L., \& Wothke, W. (1999). Amos 4.0 user's guide. Marketing Department, SPSS Incorporated.

Bagozzi, R. P., \& Yi, Y. (1998). On the evaluation of structural equation models. Journal of the Academy of Marketing Science, 16(1), 74-94.

Barney, J. B. (1991). Firm resources and sustained competitive advantage. Journal of Management, 17(1), 99-120.

Barney, J. B. (1997). Gaining and Sustaining Competitive Advantage. Reading, MA: Addison-Wesley.

Barney, J. B. (2002). Strategic management: From informed conversation to academic discipline. Academy of Management Perspectives, 16(2), 53-57.

Barney, J. B., Ketchen, D. J. Jr., \& Wright, M. (2011). The future of resource-based theory: Revitalization or Decline? Journal of Management, 37(5), 1299-1315.

Becherer, R. C., \& Maurer, J. G. (1999). The proactive personality disposition and entrepreneurial behavior among small company presidents. Journal of Small Business Management, 37(1), 28.

Bentler, P. M., \& Dudgeon, P. (1996). Covariance structure analysis: Statistical practice, theory, and directions. Annual Review of Psychology, 47(1), 563-592.

Bowman, C., \& Ambrosini, V. (2003). How the resourcebased and the dynamic capability views of the firm inform corporate-level strategy. British Journal of Management, 14(4), 289-303.

Carland, J. C., Carland, J. W., \& Stewart, W. H. (1996). Seeing what's not there: The enigma of entrepreneurship. Journal of Small Business Strategy, 7(1), 1-20.

Covin, J. G., \& Slevin, D. P. (1989). Strategic management of small firms in hostile and benign environments. Strategic Management Journal, 10(1), 75-87. 
Covin, J. G., \& Lumpkin, G. T. (2011). Entrepreneurial orientation theory and research: Reflections on a needed construct. Entrepreneurship Theory and Practice, 35(5), 855-872.

Covin, J. G., \& Miller, D. (2014). International entrepreneurial orientation: Conceptual considerations, research themes, measurement issues, and future research directions. Entrepreneurship Theory and Practice, 38(1), 11-44.

Cyert, R. M., \& March, J. G. (1963). A behavioral theory of the firm. Englewood Cliffs, NJ: Wiley-Blackwell.

Daniel, E. M., \& Wilson, H. N. (2003). The role of dynamic capabilities in e-business transformation. European Journal of Information Systems, 12(4), 282-296.

D'Aveni, R. (1994). Hypercompetition: Managing the dynamics of strategic management. New York, NY: The Free Press.

Dess, G. G., Ireland, R. D., Zahra, S. A., Floyd, S. W., Janney, J. J., \& Lane, P. J. (2003). Emerging issues in corporate entrepreneurship. Journal of Management, 29(3), 351-378.

Drucker, P. F. (1985). The discipline of innovation. Harvard Business Review, 63(3), 67-72.

Eisenhardt, K. M., \& Martin, J. A. (2000). Dynamic capabilities: What are they? Strategic Management Journal, 10(11), 1105-1121.

Fornell, C., \& Larcker, D. F. (1981). Structural equation models with unobservable variables and measurement error: Algebra and statistics. Journal of Marketing Research, 18(3), 382-388.

Gatignon, H., \& Xuereb, J-M. (1997). Strategic orientation of the firm and new product performance. Journal of Marketing Research, 34(1), 77-90.

Grant, R. M. (1996). Toward a knowledge-based theory of the firm. Strategic Management Journal, 17(S2), 109-122.

Hair, J. F., Black, W. C., Babin, B. J., Anderson, R. E., \& Tatham, R. L. (2006). Multivariate Data Analysis (6 $6^{\text {th }}$ ed). New York, NY: Prentice-Hall.

Hamel, G., \& Prahalad, C. K. (1994). Competing for the Future. Boston, MA: Harvard Business School Press.

Helfat, C. E., Finkelstein, S., Mitchell, W., Peteraf, M. A., Singh, H., Teece, D. J., \& Winter, S. G. (2009). Dynamic Capabilities: Understanding Strategic Change in Organizations. Malden, MA: Wiley-Blackwell.

Henderson, R., \& Cockburn, I. (1994), Measuring competence? Exploring firm effects in pharmaceutical research. Strategic Management Journal, 15(S1), 63-84.

Hult, G. T. M., Hurley, R. F., \& Knight, G. A. (2004). Innovativeness: Its antecedents and impact on business performance. Industrial Marketing Management, 33(5), 429-438.
Hurley, R. F., \& Hult, G. T. M. (1998). Innovation, market orientation, and organizational learning: An integration and empirical examination. Journal of Marketing, 62(3), 42-54.

King, A. A., \& Tucci, C. L. (2002). Incumbent entry into new market niches: The role of experience and managerial choice in the creation of dynamic capabilities. Management Science, 48(2), 171-186.

Kogut, B., \& Zander, U. (1992). Knowledge of the firm, combinative capabilities, and the replication of technology. Organization Science, 3(3), 383-397.

Krasnikov, A., \& Jayachandran, S. (2008). The relative impact of marketing, research-and-development, and operations capabilities on firm performances. Journal of Marketing, 72(4), 1-11.

Lassen, A. H., Gertsen, F., \& Riis, J. O. (2006). The nexus of corporate entrepreneurship and radical innovation. Creativity and Innovation Management, 15(4), 359-372

Lee, J. S., \& Hsieh, C. J. (2010). A research in relating entrepreneurship, marketing capability, innovative capability and sustained competitive advantage. Journal of Business \& Economics Research, 8(9), 109-119.

Levin, R. C. (1988), Appropriability, R\&D spending, and technological performance. The American Economic Review, 78(2), 424-428.

Levinthal, D. A., \& March, J. G. (1993). The myopia of learning. Strategic Management Journal, 14(S2), 95-112.

Lumpkin, G. T., \& Dess, G. G. (2001). Linking two dimensions of entrepreneurial orientation to firm performances: The moderating role of environment and industry life cycle. Journal of Business Venturing, 16(5), 429-451.

Lyons, B. (2000). Environmentalism as a source of corporate competitive advantage. Interdisciplinary Environmental Review, 2(2), 217-234.

Makadok, R. (2001). Toward a synthesis of the resourcebased and dynamic-capability views of rent creation. Strategic Management Journal, 22(5), 387-401.

Mahoney, J. T., \& Pandian, J. R. (1992). The resourcebased view within the conversation of strategic management. Strategic Management Journal, 13(5), 363380.

Macher, J. T., \& Boerner, C. S. (2006). Experience and scale and scope economies: Trade-offs and performance in development. Strategic Management Journal, 27(9), 845-865.

Marsh, S. J., \& Stock, G. N. (2003). Building dynamic capabilities in new product development through intertemporal integration. Journal of Product Innovation Management, 20(2), 136-148. 
McDougall, P. P., Oviatt, B. M., \& Shrader, R.C. (2003). A comparison of international and domestic new ventures, Journal of International Entrepreneurship, 1(1), 59-82.

Menguc, B., \& Auh, S. (2006). Creating a firm-level dynamic capability through capitalizing on market orientation and innovativeness. Journal of the Academy of Marketing Science, 34(1), 63-73.

Miller, D., \& Friesen, P. H. (1986). Porter's (1980) generic strategies and performance: An empirical examination with American data: part I: testing Porter. Organization Studies, 7(1), 37-55.

Morgan, R. E., \& Strong, C. A. (2003). Business performance and dimensions of strategic orientation. Journal of Business Research, 56(3), 163-176.

Morris, M. H., \& Kuratko, D. F. (2002). Corporate entrepreneurship, Entrepreneurial Development within Organizations. Nashville, TN: South-Western Pub.

Morris, M. H., \& Lewis, P. S. (1995). The determinants of entrepreneurial activity: Implications for marketing. European Journal of Marketing, 29(7), 31-48.

Morris, M. H., \& Sexton, D. L. (1996). The concept of entrepreneurial intensity: Implications for company performance. Journal of Business Research, 36(1), 5-13.

Murphy, P. J., Kickul, J., Barbosa, S. D., \& Titus, L. (2007). Expert capital and perceived legitimacy: Female-run entrepreneurial venture signalling and performance. The International Journal of Entrepreneurship and Innovation, 8(2), 127-138.

Newbert, S. L. (2005). New firm formation: A dynamic capability perspective. Journal of Small Business Management, 43(1), 55-77.

Nunnally, J. C., \& Bernstein, I. H. (1994). Psychometric Theory. New York, NY: McGraw-Hill.

Pavlou, P. A., \& El Sawy, O. A. (2011). Understanding the elusive black box of dynamic capabilities. Decision Sciences, 42(1), 239-273.

Podsakoff, P. M., \& Organ, D. (1986). Reports in organizational research: Problems and prospects. Journal of Management, 12(4), 531-545.

Porter, M. E. (1991). Towards a dynamic theory of strategy. Strategic Management Journal, 12(S2), 95-117

Priem, R. L., \& Butler, J. E. (2001). Is the resource-based "view" a useful perspective for strategic management research? Academy of Management Review, 26(1), 22-40.

Repenning, N. P., \& Sterman, J. D. (2002). Capability traps and self-confirming attribution errors in the dynamics of process improvement. Administrative Science Quarterly, 47(2), 265-295.

Rindova, V., \& Taylor, S. (2002), Dynamic capabilities as macro and micro organizational evolution. Robert $H$. Smith School of Business-Smith Papers Online, 1-11
Rosli, M. M., \& Sidek, S. (2013). The impact of innovation on the performance of small and medium manufacturing enterprises: Evidence from Malaysia. Journal of Innovation Management in Small \& Medium Enterprises, 2013(2013), 1-16. DOI: 10.5171/2013.885666

Sapienza, H. J., Autio, E., George, G., \& Zahra, S. A. (2006). A capabilities perspective on the effects of early internationalization on firm survival and growth. Academy of Management Review, 31(4), 914-933.

Schumpeter, J. A. (1934). Theory economic development. Cambridge, MA: Harvard University Press.

Stone, E. F., \& Hollenbeck, J. R. (1989). Clarifying some controversial issues surrounding statistical procedures for detecting moderator variables: Empirical evidence and related matters. Journal of Applied Psychology, 74(1), 310.

Swamidass, P. M., \& Newell, W. T. (1987), Manufacturing strategy, environmental uncertainty and performances: A path analytic model. Management Science, 33(4), 509524.

Tan, K. C., Kannan, V. R., Jayaram, J., \& Narasimhan, R. (2004). Acquisition of operations capability: a model and test across US and European firms. International Journal of Production Research, 42(4), 833-851.

Teece, D. J. (2007). Explicating dynamic capabilities: The nature and microfoundations of (sustainable) enterprise performances. Strategic Management Journal, 28(13), 1319-1350.

Teece, D. J., Pisano, G., \& Shuen, A. (1997). Dynamic capabilities and strategic management. Strategic Management Journal, 18(7), 509-533.

Vickery, S. K., Dröge, C., \& Markland, R. E. (1997). Dimensions of manufacturing strength in the furniture industry. Journal of Operations Management, 15(4), 317330.

Vorhies, D. W., \& Morgan, N. A. (2005), Benchmarking marketing capabilities for sustainable competitive advantage. Journal of Marketing, 69(1), 80-94.

Wang, C. L. (2008). Entrepreneurial orientation, learning orientation, and firm performances. Entrepreneurship Theory and Practice, 32(4), 635-657.

Weerawardena, J., \& O'Cass, A. (2004) "Exploring the characteristics of the market-driven firms and antecedents to sustained competitive advantage. Industrial Marketing Management, 33(5), 419-428.

Wiklund, J. (1999). The sustainability of the entrepreneurial orientation-performance relationship. Entrepreneurship Theory and Practice, 24(1), 37-48.

Wiklund, J., \& Shepherd, D. (2005). Entrepreneurial orientation and small business performances: A configurational approach. Journal of Business Venturing, 20(1), 71-91. 
Williamson, O. E. (1999). Strategy research: Governance and competence perspectives. Strategic Management Journal, 20(12), 1087-1108.

Wu, L. Y. (2010). Applicability of the resource-based and dynamic-capability views under environmental volatility. Journal of Business Research, 63(1), 27-31.

Zahra, S. A., \& Covin, J. G. (1995). Contextual influences on the corporate entrepreneurship-performance relationship: A longitudinal analysis. Journal of Business Venturing, 10(1), 43-58.

Zahra, S. A., Sapienza, H. J., \& Davidsson, P. (2006). Entrepreneurship and dynamic capabilities: A review, model and research agenda. Journal of Management Studies, 43(4), 917-955.

Zollo, M., \& Winter, S. G. (2002). Deliberate learning and the evolution of dynamic capabilities. Organization Science, 13(3), 339-351.

Zott, C. (2003). Dynamic capabilities and the emergence of intra-industry differential firm performances: Insights from a simulation study. Strategic Management Journal, 24(2), 97-125. 